\title{
The Human Cost of the Gulf War. How Can We Help?
}

DOI: http://dx.doi.org/10.5915/23-2-14921

We have witnessed in the past two months the most massive military conflict since World War II. The Gulf war has resulted in total devastation of Iraq and Kuwait.

From our perspective as physicians, we should be concerned with the human cost of this war and particularly with the medical needs of the people in these countries.

There has been an untold number of civilian casualties in Iraq while it is estimated that between 100,000 and 200,000 Iraqi military personnel have been killed or injured. At the same time, we know that the health care systems have collapsed, especially in Iraq. The power plants have been severely damaged. Water purification systems and sewerage disposal/treatment plants are practically inoperative. Reportedly, there is no running water in most Iraqi cities. These conditions are conducive to serious health problems, particularly infections, and probably epidemics. In addition, the embargo that has been in effect for approximately eight months has limited the availability of medicines, medical supplies, and equipment. These factors combined resulted in the inability to provide medical care to the injured and diseased.

As is expected, civilian health care is further endangered as the war-wounded take priority in receiving whatever little hospital treatment that is still available.

A team of investigators from "Physicians for Human Rights" based in Denmark and USA have toured hospitals in Baghdad and reported that a large number of children are dying from treatable diseases, because of the lack of infant milk, medications, and other medical supplies. There have been documented shortages of antibiotics, vaccines, anesthetic agents, intravenous administration sets, and other critical medical supplies.

Many organizations, both national and international, have established relief funds for the victims of war. Some have organized relief missions with medical teams and supplies. We, as Muslim physicians, should assume a more active role in providing humanitarian/medical services to those in urgent need. We, the members of the IMA, should be in the forefront of these efforts. You should have recently received a letter from Dr. Khalid Qazi, IMA President, requesting your contribution to IMA's efforts in the cause of the war victims. Please respond generously to his appeal.

Some of the Muslim organizations that I am aware of, which are taking a lead in such efforts are United American Muslims for Peace, Mercy International, and Islamic Society of North America. It would be great if you could volunteer your time. Short of that, you can certainly support these efforts by donating generously to these or other organizations providing such humanitarian services. We should remember the Qur'ānic verse:

"... And if anyone saved one human life, it would be as if he has saved all mankind...", Chapter 5, Verse 35.

Also, we should remember Prophet Muhammad's saying:

"Allāh is in the help of the person, as long as that person is helping his brother."

I invited Dr. R.U. Jafar, one of the conveners of United American Muslims for Peace, to write the following editorial about the activities of this organization.

May Allah bless our efforts and bestow his mercy on all the suffering peoples of that area.

Hossam E. Fadel, M.D. University Professional Center II 818 St. Sebastian Way, Suite 200 Augusta, GA 30901 